\title{
Analytical Determination of Heavy Metals in Various Dokha and Shisha Products, and Related Health Implications
}

\author{
Bassam Mahboub ${ }^{1}$, Ayssar Nahlée ${ }^{2 *}$, Ayesha Begum², Omar Al Assaf ${ }^{3}$, Hamdan Al Zarooni $^{3}$ and Mohmmad \\ El Hajjaj ${ }^{1}$ \\ ${ }^{1}$ Department of Clinical Sciences, College of Medicine, UAE \\ ${ }^{2}$ Department of Chemistry, College of Sciences, UAE \\ ${ }^{3}$ Department of Medical Education, Dubai Health Authority, UAE
}

*Corresponding author: Ayssar Nahlé, Department of Chemistry, College of Sciences Medicine, UAE

\section{ARTICLE INFO}

Received: 慧 December 09, 2019

Published: 㭋 December 17, 2019

Citation: Bassam Mahboub, Ayssar Nahlé, Ayesha Begum, Omar Al Assaf, Hamdan Al Zarooni, Mohmmad El Hajjaj. Analytical Determination of Heavy Metals in Various Dokha and Shisha Products, and Related Health Implications. Biomed J Sci \& Tech Res 23(5)-2019. BJSTR. MS.ID.003975.

Keywords: Heavy Metals; Dokha, Shisha; Cigarettes; UAE

\section{ABSTRACT}

Objective: In this present study twelve metals were analyzed in various Dokha and Shisha products. The analysis was carried out using Inductively Coupled Plasma Optical Emission Spectrometry (ICP-OES). All the metals were found in each sample and at various concentrations. Furthermore, the concentration of various heavy metals with e-cigarette is compared in the discussion.

Results: Dokha tobacco contained very high metal concentrations compared to Shisha and Marlboro brand cigarette tobaccos. The highest level of aluminum(Al)

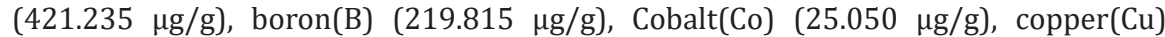
$(24.000 \mu \mathrm{g} / \mathrm{g})$, lead(Pb) $(468.620 \mu \mathrm{g} / \mathrm{g})$, and $\operatorname{zinc}(\mathrm{Zn})(342.740 \mu \mathrm{g} / \mathrm{g})$, were found in Alward Alahmar Green Dokha tobacco. Due to the significant toxicity of these metals, it is very important to control and quantify their concentrations in the tobaccos.

Abbreviations: ICP-OES: Inductively Coupled Plasma Optical Emission Spectrometry; Fe: Iron; Mn: Manganese; Zn: Zinc; Cu: Copper; Cd: Cadmium; Cr: Chromium; As: Arsenic; Be: Beryllium; Ni: Nickel; Al: Aluminum; B: Boron; Co: Cobalt; Pb: Lead; A.R.: Analytical Reagent; HNO3: Nitirc Acid; HCl: Hydrochloric Acid; EC: E-Cigarette; PDE: Permissible Daily Exposure

\section{Introduction}

Tobacco is available in the market legally although it is harmful to humans [1]. During smoking, a complex mixture of compounds is inhaled into the respiratory system affecting different organs. In 1959, some 400 compounds were known to be present in tobacco leaves and tobacco smoke; today, the figure has risen to more than 4000 [2]. Harmful metals enter the body via food, drinking water, and the air we breathe, or by skin contact. They could accumulate in the liver, kidneys, bones, pancreas, and the central nervous system where they effect the health without being noticed and diagnosed. Heavy metals can cause cancer without ever being implicated in the diagnosis. Heavy metals cause sodium retention leading to high blood pressure. They can also cause heart disease and mental retardation. Everyone is con-taminated with heavy metals, some seriously, without ever knowing it. Nonessential heavy metal ions cause aging in addition to serious diseases and death. People who are otherwise very healthy will have increased aging caused by heavy metal ions cross-linking between normal molecules in the body.

These ions are sometimes referred to as free radicals. The cross-linking has been identified in diseases such as hardening of the arteries, skin ailments, carpal tunnel syndrome, degeneration of organs, and nerve damage. When heavy metal poisoning is suspected, it is important to begin the treatment as soon as possible to minimize long-term damage to the patient's nervous system and 
digestive tract. Heavy metal poisoning is considered a medical emergency, and the patient should be taken to a hospital emergency room. Heavy metals concentrations in Dokha and Shisha tobacco products have not been extensively studied in the Middle East. Tobacco leaves are rich sources of toxic heavy metals as metals get preferentially enriched in the tobacco leaves during plant growth $[3,4]$. The use of tobacco products always puts an impact/influence on the health of smokers directly as well as non-smokers via passive smoking and adds heavy metal content to the environment $[5,6]$. Dokha is commonly smoked out of an elongated wooden pipe called a Midwakh (alternatively spelled 'Medwakh').

Hookah is a water pipe used to smoke Shisha tobacco mixture in which charcoal heated air passes through a water-filled chamber [7-10]. According to a World Health Organization advisory, a typical one-hour session of hookah smoking exposes the user to 100 to 200 times the volume of smoke inhaled from a single cigarette. Even after passing through water, tobacco smoke still contains high levels of toxic compounds including carbon monoxide, heavy metals, and cancer-causing chemicals (carcinogens) [11]. The traditional Midwakh pipes have no filters so large amount of toxic heavy metals can easily enter the lungs [12]. The content of metals in tobacco varies a lot and it depends on several factors such as soil type and $\mathrm{pH}$ genotype, use of some metal-containing pesticides, fertilizers, etc. Some of the metals such as iron (Fe), manganese $(\mathrm{Mn})$, zinc $(\mathrm{Zn})$, and copper $(\mathrm{Cu})$ are important micronutrients and they are also very important for plant growth and yield $[13,14]$. While soil factors have a large impact on the bioavailability of metals to plants, different species or varieties grown on the same soil can have different metal uptake [15].

However, other metals such as lead, cadmium, and nickel are not important for the plant growth but they can cause serious health and ecological problems, and several toxic metals as carcinogens. Cadmium (Cd), chromium (Cr), arsenic (As), beryllium (Be) and nickel (Ni) are classified as group 1 human carcinogens [16]. In shisha, the concentration of toxic elements per portion smoked is diluted by the molasses and glycerin. It is noted that the most important measure regarding the toxic metals is the amount reaching the smoker's respiratory system from the smoke. The aim of the present study is to determine the concentrations of twelve metals ( $\mathrm{Al}, \mathrm{B}, \mathrm{Cd}, \mathrm{Co}, \mathrm{Cr}, \mathrm{Cu}, \mathrm{Fe}, \mathrm{Mn}, \mathrm{Ni}, \mathrm{Pb}$, and $\mathrm{Zn}$ ) in 11 various tobaccos found in different Dokha, Shisha, and cigarette brands for sale in the UAE. The samples were analyzed by Inductively Coupled Plasma Optical Emission Spectrometry (ICP-OES).

\section{Methodology}

\section{Sample Collection and Storage}

Dokha and Shisha samples analyzed during this study such as "TURBO" Dhoka, "Alward Alahmar" Dhoka, "Yusuf Redha" Dokha, Shisha "Arguilla Premium Natural", "MAZAYA" and "Al Fakher" Shisha samples were purchased from different stores. All samples were assigned an identification number and logged into a database.
They were sealed in plastic bags and stored at $27^{\circ} \mathrm{C}$ in their original packaging until tested.

\section{Chemical Reagents and Preparation}

Analytical Reagent (A.R.) grade chemicals and reagents used for the preparation of concentrated Hydrochloric acid (HCl) A.R (37\%), concentrated Nitric acid (HNO3) A.R (65\%) were purchased from Sigma-Aldrich. ICP multi-element standard solution IV, (23 elements in diluted nitric acid) $1000 \mathrm{mg}$ was used to prepare the calibration standards used in determining the heavy metal concentration in the samples. To dilute the standard solution deionized water was used.

\section{Instrument and Apparatus}

Inductively Coupled Plasma ICP-OES (Varian-VISTA MPX) was used to determine the concentration of heavy metals. Ceramic pestle and mortar used for grinding and homogenizing the tobacco samples. Digital analytical balance (Scientech with model no SA210), and Whatman No. 42 filters (ash less-Germany) were used for weighing, and filtering the samples, respectively. All Glassware were soaked in 5\% nitric acid for $24 \mathrm{~h}$, washed with deionized water, and dried to ensure that any contamination from glassware does not occur.

\section{Preparation of Tobacco Samples}

The samples were air dried on clean watch glass and care was taken to avoid influence by dust during air drying. The dried leaves were ground using mortar and pestle and sieved with mesh sieve.

\section{Acid Digestion of Tobacco Samples}

In this present work, the solid samples were digested using acid digestion method. Digestion with acid or acid mixtures has long been the traditional method for the determination of metals in plants. It is very strong acid digestion that will dissolve all elements that could become environmentally available. About $0.2 \mathrm{~g}$ of ground tobacco leaves was weighed into a clean $125 \mathrm{~mL}$ Erlenmeyer flask. A $10 \mathrm{~mL}$ mixture of $\mathrm{HNO}_{3}(65 \%)$ and $\mathrm{HCl}(37 \%)$ with a ratio of $4: 1$ $(\mathrm{v} / \mathrm{v})$ were added and allowed to digest by heating the vessel in a water bath-shaker for $12 \mathrm{~h}$ at $100 \circ \mathrm{C}$. The mixture was finally heated strongly to a medium heat for 3 minutes and allowed to cool.

The solution was filtered using $9 \mathrm{~cm}$ diameter Whatman (No. 42) filter papers and transferred into $100 \mathrm{~mL}$ volumetric flask and made up to the mark with deionized water. The filtrate solution was stored in the refrigerator waiting for heavy metal analysis by ICP-OES. Quantification was achieved by interpolating the relevant calibration curves prepared from aqueous solutions of multielement (Merk CertiPUR-1.11355.0100, Germany) metal standards in the same acid concentration, to minimize matrix effects.

\section{Analysis of Standard Reference Materials}

All samples were analyzed for $\mathrm{Al}, \mathrm{B}, \mathrm{Cd}, \mathrm{Co}, \mathrm{Cr}, \mathrm{Cu}, \mathrm{Fe}, \mathrm{Mn}, \mathrm{Ni}$, $\mathrm{Pb}$, and $\mathrm{Zn}$ concentrations. Moreover, the precision, accuracy, and reproducibility of results for every run was started with a control, blank and testing several quality controls (QC) solutions. 


\section{Results}

Our research provided information related to possible toxic heavy metals present in Dokha and Shisha products locally sold in UAE market. The metal concentrations in various tobacco samples are presented in Table $1 \mathrm{in} \mu \mathrm{g} / \mathrm{g}$ units and plotted in Figure 1. The concentrations of each element along with range of minimum and maximum values in all samples are shown in Table 2 . The range of $\mathrm{Al}, \mathrm{B}, \mathrm{Cd}, \mathrm{Co}, \mathrm{Cr}, \mathrm{Cu}, \mathrm{Fe}, \mathrm{Mn}, \mathrm{Ni}, \mathrm{Pb}$, and $\mathrm{Zn}$ in various Dokha and Shisha products are shown as follows:

Al (8.170 to $421.235 \mu \mathrm{g} / \mathrm{g}$ ), B (3.2155 to $219.815 \mu \mathrm{g} / \mathrm{g}$ ), Cd (0.964 to $58.460 \mu \mathrm{g} / \mathrm{g}$ ), Co (0.113 to $-25.050 \mu \mathrm{g} / \mathrm{g}$ ), Cr $(0.185$ $-58.165 \mu \mathrm{g} / \mathrm{g}), \mathrm{Cu}(8.689-24.000 \mu \mathrm{g} / \mathrm{g}), \mathrm{Fe}(20.730-654.700 \mu \mathrm{g} / \mathrm{g})$, Mn (10.526-159.240 $\mu \mathrm{g} / \mathrm{g})$, Ni (2.047-59.000 $\mu \mathrm{g} / \mathrm{g}), \mathrm{Pb}(5.560-$ $468.620 \mu \mathrm{g} / \mathrm{g})$, and $\mathrm{Zn}(0.375-342.740 \mu \mathrm{g} / \mathrm{g})$.

Table 1: Concentrations of metals ( $\mu \mathrm{g} / \mathrm{g}$ tobacco) in various Dokha and Shisha brands.

\begin{tabular}{|c|c|c|c|c|c|c|c|c|c|c|c|c|}
\hline \multicolumn{13}{|c|}{$\mu \mathrm{g} / \mathrm{g}$ Tobacco } \\
\hline No. & Brands & Al & B & Cd & Co & $\mathrm{Cr}$ & $\mathrm{Cu}$ & $\mathrm{Fe}$ & Mn & $\mathrm{Ni}$ & $\mathbf{P b}$ & Zn \\
\hline D1 & $\begin{array}{l}\text { Alward Alahmar } \\
\text { Green Dokha }\end{array}$ & 421.235 & 219.815 & 1.707 & 25.050 & 2.926 & 24.000 & 420.050 & 58.240 & 8.453 & 468.620 & 342.740 \\
\hline D2 & $\begin{array}{c}\text { Alward Alahmar } \\
\text { Red Dokha }\end{array}$ & 110.660 & 162.005 & 1.309 & 2.849 & 2.794 & 11.737 & 460.515 & 52.850 & 11.108 & 384.975 & 43.590 \\
\hline D3 & $\begin{array}{c}\text { Alward Alahmar } \\
\text { Gold Dokha }\end{array}$ & 142.125 & 101.530 & 1.627 & 1.311 & 4.361 & 15.818 & 293.570 & 10.526 & 33.053 & 449.890 & 32.647 \\
\hline D4 & $\begin{array}{l}\text { Yusuf Redha } \\
\text { Dokha-Gold } 50\end{array}$ & 114.865 & 3.216 & 1.887 & 2.411 & 3.416 & 20.651 & 340.170 & 58.135 & 28.727 & 315.595 & 6.341 \\
\hline D5 & $\begin{array}{l}\text { Yusuf Redha } \\
\text { Dokha-White }\end{array}$ & 196.400 & 64.320 & 1.283 & 0.113 & 47.004 & 18.618 & 374.430 & 57.105 & 8.619 & 265.780 & 6.124 \\
\hline D6 & $\begin{array}{l}\text { TURBO Dokha } \\
\text { Premium-3 }\end{array}$ & 124.030 & 40.718 & 1.487 & 3.368 & 3.365 & 8.689 & 334.125 & 66.575 & 7.063 & 363.870 & 6.402 \\
\hline D7 & $\begin{array}{l}\text { TURBO Dokha } \\
\text { Premium-1 }\end{array}$ & 231.575 & 162.455 & 58.460 & 2.818 & 7.932 & 19.248 & 654.700 & 51.345 & 6.893 & 438.170 & 7.262 \\
\hline D8 & $\begin{array}{l}\text { Yusuf Redha } \\
\text { Dokha-Blue } 50\end{array}$ & 8.170 & 124.595 & 5.865 & 0.652 & 7.713 & 10.293 & 20.730 & 159.240 & 2.237 & 81.630 & 8.024 \\
\hline D9 & $\begin{array}{c}\text { TURBO Dokha } \\
\text { Black-2 }\end{array}$ & 172.150 & 81.465 & 0.964 & 2.940 & 1.372 & 11.555 & 345.150 & 54.645 & 18.594 & 403.515 & 5.241 \\
\hline D10 & $\begin{array}{l}\text { TURBO Dokha } \\
\text { Premium-2 }\end{array}$ & 219.220 & 98.275 & 1.771 & 1.945 & 2.870 & 17.694 & 301.905 & 52.475 & 2.047 & 345.450 & 4.191 \\
\hline S1 & $\begin{array}{l}\text { Shisha Arguilla } \\
\text { (Iranian) }\end{array}$ & 167.180 & 58.160 & 1.126 & 3.019 & 0.185 & 15.751 & 312.125 & 71.520 & 2.191 & 197.485 & 3.359 \\
\hline S2 & $\begin{array}{c}\text { MAZAYA } \\
\text { Watermelon Mint } \\
\text { Shisha } \\
\end{array}$ & 22.165 & 29.570 & 1.318 & 1.831 & 58.165 & 14.566 & 96.235 & 22.095 & 59.000 & 5.560 & 0.375 \\
\hline S3 & $\begin{array}{l}\text { Al Fakher Double } \\
\text { Apple Shisha }\end{array}$ & 14.905 & 15.075 & 4.960 & 5.977 & 1.380 & 13.795 & 62.480 & 11.095 & 73.730 & 24.155 & 1.530 \\
\hline S4 & $\begin{array}{c}\text { Marlboro Cigarette } \\
\text { Tobacco }\end{array}$ & 41.829 & 12.110 & 3.775 & 2.634 & 1.010 & 17.245 & 249.435 & 136.870 & 31.495 & 78.965 & 3.910 \\
\hline
\end{tabular}

Table 2: Minimum and maximum concentrations of heavy metals ( $\mu \mathrm{g} / \mathrm{g}$ tobacco) in various Dokha and Shisha brands.

\begin{tabular}{|c|c|c|c|c|}
\hline Metal & $\begin{array}{c}\text { Minimum Level }(\mu \mathrm{g} / \mathrm{g} \\
\text { Tobacco) }\end{array}$ & Brand & $\begin{array}{c}\text { Maximum Level }(\boldsymbol{\mu g} / \mathbf{g} \\
\text { Tobacco) }\end{array}$ & Brand \\
\hline $\mathbf{A l}$ & $\mathbf{8 . 1 7 0}$ & (D8) Yusuf Redha Dokha - Blue 50 & $\mathbf{4 2 1 . 2 3 5}$ & (D1) Alward Alahmar - Green Dokha \\
\hline $\mathbf{B}$ & $\mathbf{3 . 2 1 5 5}$ & (D4) Yusuf Redha Dokha - Gold 50 & $\mathbf{2 1 9 . 8 1 5}$ & (D1) Alward Alahmar - Green Dokha \\
\hline Cd & $\mathbf{0 . 9 6 4}$ & (D9) TURBO Dokha Black-2 & $\mathbf{5 8 . 4 6 0}$ & (D7) TURB0 Dokha - Premium-1 \\
\hline Co & $\mathbf{0 . 1 1 3}$ & (D5) Yusuf Redha Dokha - White & $\mathbf{2 5 . 0 5 0}$ & (D1) Alward Alahmar - Green Dokha \\
\hline $\mathbf{C r}$ & $\mathbf{0 . 1 8 5}$ & (S1) Shisha Arguilla (Iranian) & $\mathbf{5 8 . 1 6 5}$ & (S2) MAZAYA Watermelon Mint Shisha \\
\hline $\mathbf{C u}$ & $\mathbf{8 . 6 8 9}$ & (D6) TURBO Dokha - Premium-3 & $\mathbf{2 4 . 0 0 0}$ & (D1) Alward Alahmar - Green Dokha \\
\hline $\mathbf{F e}$ & $\mathbf{2 0 . 7 3 0}$ & (D8) Yusuf Redha Dokha-Blue 50 & $\mathbf{6 5 4 . 7 0 0}$ & (D7) TURB0 Dokha - Premium-1 \\
\hline $\mathbf{M n}$ & $\mathbf{1 0 . 5 2 6}$ & (D3) Alward Alahmar - Gold Dokha & $\mathbf{1 5 9 . 2 4 0}$ & (D8) Yusuf Redha Dokha-Blue 50 \\
\hline $\mathbf{N i}$ & $\mathbf{2 . 0 4 7}$ & (D10) TURBO Dokha Premium-2 & $\mathbf{5 9 . 0 0 0}$ & (S2) MAZAYA Watermelon Mint Shisha \\
\hline $\mathbf{P b}$ & $\mathbf{5 . 5 6 0}$ & (S2) MAZAYA Watermelon Mint Shisha & $\mathbf{4 6 8 . 6 2 0}$ & (D1) Alward Alahmar - Green Dokha \\
\hline
\end{tabular}




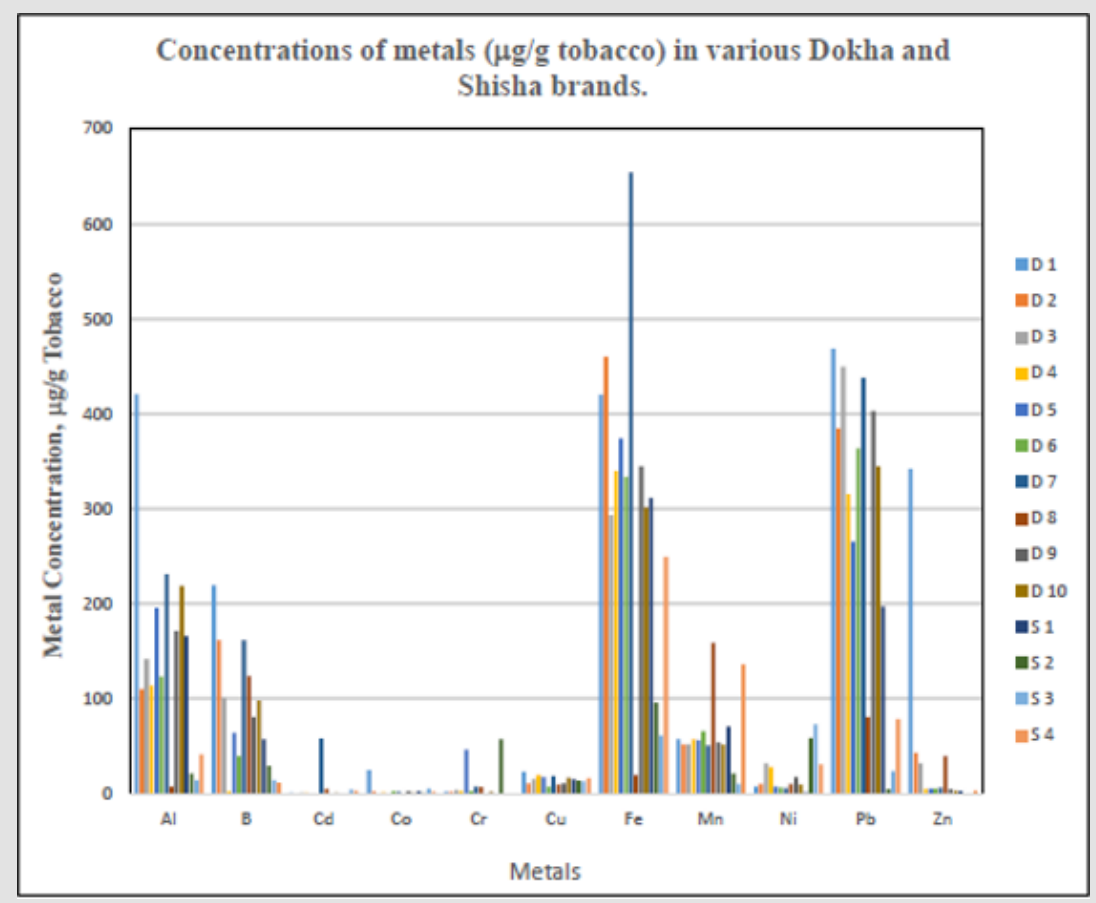

Figure 1: Concentrations of metals $(\mu \mathrm{g} / \mathrm{g}$ tobacco) in various Dokha and Shisha brands.

\section{Discussion}

\section{Dokha Discussion}

Aluminum: The Al levels in the studied samples ranged from $8.170 \mu \mathrm{g} / \mathrm{g}$ to $421.235 \mu \mathrm{g} / \mathrm{g}$. The highest concentration was found in the "Alward Alahmar Green Dokha" and the lowest in "Yusuf Redha Dokha-Blue 50". In humans, $\mathrm{Al}$ replaces $\mathrm{Mg}^{2}+$ and $\mathrm{Fe}^{3+}$, which causes many disturbances associated with intercellular communication, cellular growth and secretory functions. The greatest complications of aluminum toxicity are neurotoxicity effects such as neuronal atrophy in the locus ceruleus, substantia nigra and striatum.

Boron: The concentration of boron varied from sample to another; and its highest concentration was found in "Alward Alahmar Green Dokha" (219.815 $\mu \mathrm{g} / \mathrm{g}$ ); while the lowest boron concentration was found in "Yusuf Redha Dokha-Gold 50" (3.2155 $\mu \mathrm{g} / \mathrm{g})$.

Cadmium: Cadmium (Cd) is highly toxic, and is one of the most important heavy metals, when the adverse health effects of smoking are considered. It can cause bone mineralization either through renal dysfunction or bone damage. Inhaling higher levels of cadmium can cause severe damage to the lungs [17]. The analysis showed that "TURBO Dokha Premium-1" contained very high concentration of cadmium $(58.460 \mu \mathrm{g} / \mathrm{g})$ compared to the rest of the studied tobaccos which ranged from $1 \mu \mathrm{g} / \mathrm{g}$ to $5 \mu \mathrm{g} / \mathrm{g}$. This high content of cadmium classifies the "TURBO Dokha Premium-1" tobacco among other poisoning products.

Cobalt: Cobalt is an essential element but at high concentrations, it becomes toxic and mainly effects the central nervous system. In addition, cardiovascular and kidney diseases and lung fibrosis are potential effects of long-term chronic exposure to nickel [18].

Chromium: Moreover, exposure to chromium compounds can result in the formation of ulcers, which will persist for months and heal very slowly. Ulcers on the nasal septum are very common in case of chromate workers. Exposure to higher amounts of chromium compounds in humans can lead to the inhibition of erythrocyte glutathione reeducates, which in turn lowers the capacity to reduce methemoglobin to hemoglobin $[19,20]$.

Iron: Furthermore, a very high level of iron enters the body crossing the rate-limiting absorption step hence becoming saturated. These free irons penetrate cells of the heart, liver, and brain. The free iron can also lead to lipid peroxidation, which results in severe damage to mitochondria, microsomes, and other cellular organelles [21]. In the analyzed samples the Fe concentrations ranged from $20.730 \mu \mathrm{g} / \mathrm{g}$ (Yusuf Redha Dokha-Blue 50) to 654.700 $\mu \mathrm{g} / \mathrm{g}$ (TURBO Dokha Premium-1).

Lead: Toxicity of lead, also called lead poisoning, can be either acute or chronic. Acute exposure can cause loss of appetite, headache, hypertension, abdominal pain, renal dysfunction, fatigue, sleeplessness, arthritis, hallucinations, and vertigo. Chronic exposure of lead can result in mental retardation, birth defects, psychosis, autism, allergies, dyslexia, weight loss, hyperactivity, paralysis, muscular weakness, brain damage, kidney damage and may even cause death [22]. The Pb levels were high in most of the analyzed samples and the lowest levels were found in "MAZAYA Watermelon Mint Shisha" (5.560 $\mu \mathrm{g} / \mathrm{g}$ ), and "Al Fakher Double 
Apple Shisha" (24.155 $\mu \mathrm{g} / \mathrm{g}$ ); whereas the highest level was found in "Alward Alahmar Green Dokha" (468.620 $\mu \mathrm{g} / \mathrm{g}$ ).

From the results shown in Table 1, "Alward Alahmar Green Dokha" had the highest content of $\mathrm{Al}, \mathrm{B}, \mathrm{Co}, \mathrm{Cu}, \mathrm{Pb}$, and $\mathrm{Zn}$. This dokha product was found to be the most hazardous compared to the other analyzed tobacco samples.

"TURBO Dokha Premium-1" was found to contain the highest level of cadmium $(58.460 \mu \mathrm{g} / \mathrm{g})$, whereas the cadmium level did not exceed $5 \mu \mathrm{g} / \mathrm{g}$ in all the other tobacco samples. Apart from its high level of cadmium, "TURBO Dokha Premium-1" also contained high levels of $\mathrm{Al}(231.575 \mu \mathrm{g} / \mathrm{g}), \mathrm{B}(162.455 \mu \mathrm{g} / \mathrm{g}), \mathrm{Fe}(654.700 \mu \mathrm{g} / \mathrm{g})$, and $\mathrm{Pb}(438.170 \mu \mathrm{g} / \mathrm{g})$. It is worth noting that "Al Fakher Double Apple Shisha" contained small concentrations of the heavy metals compared to the other studied tobaccos. This was also noticed with the Marlboro Cigarette Tobacco with the exception of its high contents of $\mathrm{Fe}, \mathrm{Mn}$, and $\mathrm{Pb}$. "Dokha" tobacco has been very much spread among youngsters and a wide variety of this product is available in the market. Smoking "dokha" is very damaging since $100 \%$ of the smoke is directly inhaled to the lungs and no pauses exist between one inhale and the other as it is common with cigarettes, cigars, and shisha smoking.

\section{Heavy Metal and E-Cigarettes}

E-cigarette (EC) has been widely considered safer than other forms of smoking [23]. However, recently the health hazards are becoming a widely questionable aspect. Propylene glycol and vegetable glycerin being toxic to cells [24] and acrolein, used to kill weeds, that causes acute lung injury, asthma, lung cancer and Chronic Obstructive Pulmonary Disease [25]. A number of published researches have studied the level of heavy metal in e-cigarettes. Farsalinos et al. published a review article and concluded that heavy metals produced from e-cigarette aerosol are considered "safe", do not produce a significant health adverse effect and produce metals at a lesser concentration than the Permissible Daily Exposure (PDE) defined by the U.S levels from inhalational medications. However, they recommend that companies should further reduce unnecessary exposure to metals [26]. Conversely, Olmedo et al. found that e-cigarette contain CR, Ni, PB, Mn and Zn in toxic concentration to humans [27].

\section{Conclusion}

Smokers are exposed to a variety of hazardous toxic heavy metals which are present in tobaccos and damage their health as well as the environment. The sources of these heavy metals are closely related to the soil, fertilizers, irrigation, manufacturing processes, types of additives, and other factors. In this present work, twelve metals ( $\mathrm{Al}, \mathrm{B}, \mathrm{Cd}, \mathrm{Co}, \mathrm{Cr}, \mathrm{Cu}, \mathrm{Fe}, \mathrm{Mn}, \mathrm{Ni}, \mathrm{Pb}$, and $\mathrm{Zn}$ ) were analyzed in various Dokha and Shisha products. The metal concentrations varied from one tobacco product to another. High levels of Fe and $\mathrm{Pb}$ were found in almost all the Dokha tobacco brands. The trace metals in the Dokha and Shisha tobaccos, are important to assure a good reference point for future studies, which will give formulations to the popular suppliers. Awareness on the heavy metals content in "Dokha" and other tobaccos and their related health implications must be publicized in order to reduce the number of smokers and to aim for a healthy society. In order to regulate the heavy metals content of tobacco and to protect smokers from heavy metals exposure international legislation should be passed.

In conclusion, awareness on the heavy metals content in "Dokha" and other tobaccos and their related health implications must be publicized in order to reduce the number of smokers and to aim for a healthy society. In order to regulate the heavy metals content of tobacco and to protect smokers from heavy metals exposure international legislation should be passed.

\section{Limitations}

The main limitation of our study is the inability of measuring all the types of "Midwakh" in the market.

\section{Declaration}

\section{Ethics Approval and Consent to Participate}

No ethics approval needed since no human participants are involved.

\section{Consent for Publication}

Not applicable.

\section{Availability of Data and Materials}

The datasets used and/or analyzed during the current study are presented within the manuscript and available from the corresponding author on reasonable request.

\section{Competing Interests}

The authors declare that they have no competing interests.

\section{Funding}

This work was supported by University of Sharjah grant No. (REC-16-06-02-S) granted for Dr. Bassam Mahboub as a faculty research fund. Dr. Bassam Mahboub has structured the idea, helped in literature review and went through the final article.

\section{Authors' Contributions}

a) B.M.: Structured the idea of the research and helped in the literature review. In addition to going through the final article for publication.

b) A.N.: Has written the result and discussion section. In addition to validating the methodology.

c) A.B.: Has written the methodology section and underwent the chemical experiment.

d) O.A.: Has provided the material for research and written the introduction section. In addition to helping in the literature review. 
e) H.Z.: Has provided the material, written the abstract, helped in the introduction. In addition to helping in the literature review.

f) M.E.: Has edited the discussion and reviewed the final manuscript.

All authors have read and approved the manuscript.

\section{Acknowledgment}

The authors are thankful to the College of Medicine at the University of Sharjah for funding this research project, and special thanks to the Department of Chemistry at the College of Sciences for providing the research facilities. We are grateful to Ms. Lubna Chaabi for her assistance during the ICP measurements.

\section{References}

1. World Health Organization (2008) WHO report on the global tobacco epidemic. The MPOWER package. World Health Organization, Geneva, Switzerland.

2. Stedman RL (1968) Chemical composition of tobacco and tobacco smoke. Chemical Reviews 68(2): 153-207.

3. Schneider G, Krivan V (1993) Multi-element analysis of tobacco and smoke condensate by instrumental neutron activation analysis and atomic absorption spectrometry. International Journal of Environmental Analytical Chemistry 53(2): 87-100.

4. Golia EE, Dimirkou EA, Mitsios IK (2007) Accumulation of metals on tobacco leaves (primings) grown in an agricultural area in relation to soil. Bull Environ Contam Toxicol 79(2): 158-162.

5. Stephens WE, Calder A, Newton J (2005) Source and health implications of high toxic metal concentrations in illicit tobacco products. Environ Sci Technol 39(2): 479-488.

6. Gala_zyn Sidorczuk M, Brzóska MM, Moniuszko Jakoniuk J (2008) Estimation of polish cigarettes contamination with cadmium and lead and exposure to these metals via smoking. Environ Monit Assess 137(13): 481-493.

7. Tobacco Free Initiative.

8. Al Houqani M, Ali R, Hajat C (2012) Tobacco Smoking Using Midwakh Is an Emerging Health Problem Evidence from a 9. Large Cross-Sectional Survey in the United Arab Emirates. PLoS One 7(6): e39189.

9. Al Shemmari N, Shaikh RB, Sreedharan J (2015) Prevalence of Dokha Use among Secondary School Students in Ajman, United Arab Emirates. Asian Pacific journal of cancer prevention: APJCP 16(2): 427-430.

10. Hookah smoking. A growing threat to public health.

11. World Health Organization (2015) TobReg - Advisory Note Waterpipe Tobacco Smoking: Health Effects, Research Needs and Recommended Actions by Regulators.
12. Ballard JA (1992) Health effects of passive smoking. Professional Safety 37(10): 28.

13. Golia EE, Mitsios IK, Tsadilas CD (2003) Concentration of heavy metals in tobacco leaves (Burley, Virginia and Oriental) in Thessaly region. Central Greece. $8^{\text {th }}$ International symposium on soil and plant analysis. 13-17, Cape Town, South Africa.

14. Zaprjanova P, Boshinova R (2004) Heavy Metal Content in Virginia and Burley Tobacco. Ecology and Future 3: 25-29.

15. Miles LJ, Parker GR (1979) Heavy metal interaction for Andropogon scoparius and Rudbeckia hirta grown on soil from urban and rural sites with heavy metal additions. J Environ Qual 8(4): 443-449.

16. IARC (2006) Overall evaluations of carcinogenicity to humans (As evaluated in IARC Monographs Volumes 1-95, last updated 13 December 2006), International Agency for Research on Cancer, Lyon.

17. Bernard A (2008) Cadmium \& its adverse effects on human health. Indian J Med Res 128(4): 557-64.

18. Kazi TG, Jalbani N, Arain MB, Jamali MK, Afridi HI, et al. (2009) Toxic metals distribution in different components of Pakistanian imported cigarettes by electrothermal atomic absorption spectrometer. J Hazard Mater 163(1): 302-307.

19. Koutras GA, Schneider AS, Hattori M, Valentine WN (1965) Studies on chromated erythrocytes. Mechanisms of chromate inhibition of glutathione reductase. Br J Haematol 11(3): 360-369.

20. Schlatter C, Kissling U (1973) Acute fatal bichromate poisoning. Beitrage zur Gerichtlichen Medizin 30: 382-388.

21. Albretsen J (2006) The toxicity of iron, an essential element. Veterinary medicine 101(2): 82-90.

22. Martin S, Griswold W (2009) Human health effects of heavy metals. Environmental Science and Technology Briefs for Citizens 15: 1-6.

23. Farsalinos KE, Polosa R (2014) Safety evaluation and risk assessment of electronic cigarettes as tobacco cigarette substitutes: A systematic review. Ther Adv Drug Saf 5(2): 67-86.

24. Sassano MF, Davis ES, Keating JE, Zorn BT, Kochar TK, et al. (2018) Evaluation of e-liquid toxicity using an open-source high-throughput screening assay. PLoS Biol 16(3): e2003904.

25. Bein K, Leikauf GD (2011) Acrolein - A pulmonary hazard. Mol Nutr Food Res 55(9): 1342-1360.

26. Farsalinos KE, Voudris V, Poulas K. (2015) Are Metals Emitted from Electronic Cigarettes a Reason for Health Concern? A Risk-Assessment Analysis of Currently Available Literature. Int J Environ Res Public Health 12(5): 5215-5232.

27. Olmedo P, Goessler W, Tanda S, Grau Perez M, Jarmul S, et al. (2018) Metal Concentrations in e-Cigarette Liquid and Aerosol Samples: The Contribution of Metallic Coils. Environmental Health Perspectives. 126(2): 027010. 
ISSN: 2574-1241

DOI: $10.26717 /$ BJSTR.2019.23.003975

Ayssar Nahlé. Biomed J Sci \& Tech Res

(C) 9 This work is licensed under Creative

Submission Link: https://biomedres.us/submit-manuscript.php

$\begin{array}{ll}\text { BIOMEDICAL } & \text { Assets of Publishing with us } \\ \text { RESEARCHES } & \text { Global archiving of articles } \\ \text { - Immediate, unrestricted online access } & \text { - Rigorous Peer Review Process } \\ & \text { - Authors Retain Copyrights } \\ \end{array}$

